Check for updates

Cite this: Mater. Adv., 2020, 1,1817

Received 4th July 2020,

Accepted 25th July 2020

DOI: 10.1039/d0ma00477d

rsc.li/materials-advances

\title{
Bio-inspired perylene diimide coated super paramagnetic nanoparticles for the effective and efficient removal of lead(II) from aqueous medium $\uparrow$
}

\author{
Sucharita Dey, ${ }^{a}$ Shouvik Mahanty, ${ }^{b}$ Ankita Saha, ${ }^{a}$ Prince Kumar, ${ }^{a}$ Rajdeep Saha, ${ }^{a}$ \\ Chirantan Kar, (D) a Punarbasu Chaudhurib and Pradip Kr. Sukul (D)*a
}

\begin{abstract}
Instability in water, the complexity of separation of the toxic substances produced and reusability issues for the reported materials used for the decontamination of lead from water are the hindrances that have caught the attention of the modern scientific community over the last few decades, resulting in the creation of an important field of research, the purification of heavy metals from water. Here, we unveil a unique ensemble, the perylene diimide coated magnetic nanoparticle, which is a conglomerate of ultra-photo stable perylene diimide [PDI] functionalized with biocompatible amino acid (levodopa) i.e. $1-3,4$-dihydroxyphenylalanine (L-DOPA) capping the superparamagnetic $\mathrm{Fe}_{3} \mathrm{O}_{4}$ nanoparticle core, for the removal of lead from contaminated water. The nanomaterial has a very simple magnetic mechanism to remove lead from water involving chelation between the lead and the L-DOPA of PDI with an exceptionally high efficiency. The characterization of the nanomaterial was substantiated by Fourier-transform infrared spectroscopy (FTIR), X-ray diffraction (XRD) analysis, high-resolution transmission electron microscopy (HR-TEM) and a physical property measurement system (PPMS). All of the materials ( $\mathrm{PDI}, \mathrm{Fe}_{3} \mathrm{O}_{4}$ ) are low in cost, nontoxic, and can be easily synthesized with an outstanding adsorption capacity of $1407.5 \mathrm{mg} \mathrm{g}^{-1}$ and a $K_{\mathrm{d}}$ value of $1.14 \times 10^{6} \mathrm{~mL} \mathrm{~g}^{-1}$. This material can effectively reduce the $\mathrm{Pb}(॥)$ concentration from 4000 to $7 \mathrm{ppb}$, well below the acceptable limit for drinking water standards and can effectively perform at a low pH level with a $99.97 \%$ efficiency. This amazing doughnut-shaped duo of PDI and $\mathrm{Fe}_{3} \mathrm{O}_{4}$ nanoparticle will make a significant contribution to the field of lead removal from water.
\end{abstract}

\section{Introduction}

On the Earth, the presence of life makes our planet unparalleled to the rest of the universe, and one of the pillars on which our biological empire is built is water. The earth is made up of $70 \%$ water and $97.5 \%$ of it is held by the oceans, leaving only $2.5 \%$ as drinkable water. ${ }^{1}$ The crisis of drinkable water is further exacerbated by our ever-increasing hunger for industrialization. ${ }^{2}$ From the very inception of industrialization and urbanization, waste products have been imposing alarming threats to both aquatic and terrestrial life. .,4 $^{3,4}$

\footnotetext{
${ }^{a}$ Department of Chemistry, Amity Institute of Applied Sciences, Amity University Kolkata, Action Area-II, Kadampukur, New Town, Rajarhat, Kolkata-700135, India.E-mail: pksukul@kol.amity.edu, sukul.ochem@gmail.com

${ }^{b}$ Department of Environmental Science, University of Calcutta, Kolkata-700019, India

$\dagger$ Electronic supplementary information (ESI) available: Zeta potential, $\mathrm{pH}$ dependent adsorption efficiency, and reusability of nanoparticle measurements. See DOI: $10.1039 /$ d0ma00477d
}

Lead toxicity is associated with various human diseases. ${ }^{5}$ Lead can bind with proteins and metabolites. ${ }^{6-8}$ It also has an extremely vicious property, where it can mimic ions ${ }^{8}$ such as $\mathrm{Ca}^{2+}, \mathrm{Mg}^{2+}, \mathrm{Fe}^{2+}$, and $\mathrm{Zn}^{2+}$ and interfere with their biological roles in our body, giving rise to problems such as anemia and neurological dysfunction in children. ${ }^{8-13}$ It is also a potent carcinogenic substance and systemic poison, causing reproductive disorders. ${ }^{13-16}$ In fish, subtle, sub-lethal, physiological responses occur at a very low concentration of lead(II) in water. ${ }^{17,18}$ Lead is a versatile element that is ductile, durable, malleable, dense, a poor conductor of electricity and highly resistant towards corrosion; no wonder it has been used in water pipe and paint industries for years. Many incidents of lead pollution in India and the USA have come to light in the past decade. ${ }^{19-23}$ The maximum permissible limit of lead(II) in water discharge is a concentration of $0.1 \mathrm{mg} \mathrm{L}^{-1}$ for wastewater, whereas 15 and $10 \mu \mathrm{g} \mathrm{L}^{-1}$ is permissible in drinking water, respectively, as set by the EPA (Environmental Protection Agency) and WHO (World Health Organization). ${ }^{24-27}$ 
Researchers are striving to find different ways to purify water from lead contamination. Traditional methods such as membrane filtration, electrochemical methods, chemical precipitation, sorbents or ion exchange including nanomaterials, chelating polymers, clay, zeolite, and so forth all have advantages and disadvantages. ${ }^{28-33}$ Chemical precipitation generates sludge as a secondary pollutant and toxic fumes, it has a low efficiency, reduced selectivity and specificity, and moderate affinity towards heavy metal separation. ${ }^{34}$ Electrochemical and sorbent methods are effective for selective heavy metals at optimal $\mathrm{pH}$ and at certain concentrations, however, they demand costly resources and are ineffective for small scale production. ${ }^{35-37}$ Membrane purification such as micellar enhanced ultrafiltration, reverse osmosis, nanofiltration, and polymer-enhanced ultrafiltration, albeit a better choice, have the disadvantages of a high expense, membrane fouling and limiting feeding flaws which fail to match the reality of industrially relevant scales. ${ }^{33-41}$ In the contemporary world of research, nanomaterials and metal-organic frameworks (MOFs) have been explored for separating heavy metals from water owing to their high surface area and adsorption capacity. For example, MOFs, a very popular method nowadays, were used by $\mathrm{Yu}$ and coworkers to develop $\mathrm{Zn}$ (II)-based MOFs decorated with $\mathrm{O}^{-}$groups for the removal of $\mathrm{Pb}^{2+}$, resulting in an adsorption capacity of $616.64 \mathrm{mg} \mathrm{g}^{-1} .^{42}$ In 2018, Sun and his team developed a MOF-polymer composite of Fe-BTC (1,3,5-benzenetricarboxylate)/polydopamine to remove lead(II) from water with a maximum adsorption capacity of $394 \mathrm{mg} \mathrm{g}^{-1} \cdot{ }^{43}$ In 2019, nanotube-like Tb-based MOFs (Tb-MOFs) were also introduced by $\mathrm{Zhu}$ et al. for removing $\mathrm{Pb}^{2+}$ from water with an adsorption capacity of $547 \mathrm{mg} \mathrm{g}^{-1} \cdot{ }^{44}$ Cao and his team developed magnesium oxide nanostructures with the highest capacities of adsorption (1980 $\mathrm{mg} \mathrm{g}^{-1}$ ) for $\mathrm{Pb}$ (II). ${ }^{45}$ Despite being advanced, these methods suffer from a few major setbacks such as lack of stability in aqueous media, $\mathrm{pH}$ dependence, complexity in purification of the compound itself from water after its use, and inability to withstand a harsh chemical environment. On the other hand, a superparamagnetic core coated with organic molecules can be a better choice in case of water treatment as solid-liquid separation becomes much easier and faster than the centrifugation or filtration technique and its small size has a larger surface area; but they still fall behind owing to their instability in acidic media, poor dispersibility in water and their biocompatibility. There are a few reports on superparamagnetic nanomaterials for water purification with high adsorption efficiencies of lead(II). Superparamagnetic $\mathrm{Fe}_{3} \mathrm{O}_{4}$ nanoadsorbents ${ }^{46-50}$ are also easily separated from water by magnetization, leaving behind no toxic side reactions. However, they usually suffer from instability in aqueous solution, and involve an undesirable interaction with non-heavy alkaline earth metals. These are the major setbacks of the superparamagnetic materials. Charpentier et al. developed a method of heavy metal removal using superparamagnetic chitosan (CS) and carboxymethylchitosan (CMC) nanocomposites in 2016 with a moderate adsorption capacity of $243 \mathrm{mg} \mathrm{g}{ }^{-1} .^{46}$ In 2014, Kumar and his team prepared graphene oxide- $\mathrm{MnFe}_{2} \mathrm{O}_{4}$ magnetic nanohybrids that showed an adsorption capacity for lead(II) from water of $673 \mathrm{mg} \mathrm{g}^{-1} \cdot{ }^{49}$ In 2017 ,
Bagbi et al. reported L-cysteine functionalized nanoparticles for lead adsorption, which gave a very low Langmuir adsorption, for example $18.8 \mathrm{mg} \mathrm{L}^{-1} \cdot{ }^{50}$ Keeping all of the aforementioned drawbacks in mind, our pivotal vision in this study was to transform this superparamagnetic core coated material concept into a costefficient, metal-specific nanomaterial that is highly dispersible in water and has a high efficiency that can cope with both larger and smaller scale lead removal from water.

Herein, we report a novel material, by developing a levodopa (L-DOPA) functionalized perylene diimide (LDPI) coated amphiphilic superparamagnetic nanomaterial (NPLD) for the decontamination of lead from water. We have coated the magnetic core with perylene diimide (PDI) which is best known for its robust nature, chemical and thermal inertness, high photo-stability and stability in acidic medium ${ }^{51-54}$ that allows our compound to withstand in industrial wastewater environment that usually degrades organic molecules. Perylene diimides (PDIs) are best known as n-type semiconductors and have received immense attention in the field of organic optoelectronics owing to their tunable electronic structure and properties. ${ }^{55-58}$ However, the application of PDIs for the purification of water is rare. LDPI has a severe tendency towards aggregation in water and $\pi-\pi$ stacking interactions, it also has high photo-stability, high fluorescent quantum yield, and minimal cost of synthesis, which is appended with the naturally occurring amino acid L-DOPA at the imide position. L-DOPA is the precursor to dopamine, it can cross the protective blood-brain barrier and is used as a neuro drug for Parkinson's disease ${ }^{59}$ to increase the dopamine concentration, this indicates that it is highly biocompatible and not at all toxic in nature. Reportedly, L-DOPA captures lead(II) selectively from waste water, for example in 2017, Zhang et al. reported polydopamine microspheres for capturing lead(II) selectively in the presence of competitive calcium(II), sodium(I), and magnesium(II) ions. ${ }^{60}$ Rybtchinski et al. successfully used fabricated supramolecular membrane of PDI for size selective ultrafiltration of nanoparticles by using its reversible self-assembly. ${ }^{53}$ In 2014 , Xing and his group developed functionalized PDI based magnetic nanoplatforms for purification and detection of bacterial lipopolysaccharides. ${ }^{54}$ Considering these attractive properties of PDI as a purifying material, PDI and L-DOPA were handpicked to make an aggregated ring like doughnut, surrounding the center filled with magnetic $\mathrm{Fe}(\mathrm{III}) / \mathrm{Fe}(\mathrm{II})$. This merges the sporadic duo into an invincible particle to withdraw $\mathrm{Pb}^{2+}$ from water, acting like a magnet with an exceptionally high adsorption capacity of $1407.5 \mathrm{mg} \mathrm{g}^{-1}$ and a $K_{\mathrm{d}}$ value of $1.14 \times 10^{6} \mathrm{~mL} \mathrm{~g}^{-1}$.

\section{Experimental section}

\section{Materials}

Perylene-3,4:9,10-tetracarboxylic dianhydride (PTCDA) and L-DOPA were purchased from Sigma-Aldrich and used as received. LDPI was synthesized according to a previously reported method. For all experiments and spectroscopic measurements, HPLC grade water or MilliQ water were used. 


\section{Instruments}

${ }^{1} \mathrm{H}$-NMR spectra were taken at $25{ }^{\circ} \mathrm{C}$ in ppm (parts per million) using $500 \mathrm{MHz}$ spectrometers (Bruker). The Fourier-transform infrared (FT-IR) spectra were collected using KBr pellets of experimental samples in an FTIR 8400S instrument (Shimadzu). The high-resolution transmission electron microscopy (HRTEM) images of the nanomaterials were observed using a JEOL HR-TEM microscope operating at $200 \mathrm{kV}$. The magnetic measurements were performed using a cryogenic physical property measurement system (PPMS). Neodymium disc magnets (strength: 0.4-0.6 Tesla) with a diameter of $13 \times 4 \mathrm{~mm}$ were used to separate the magnetic nanoparticles from the water. The quantitative analysis of the metal ions was carried out using a Thermo Scientific iCAP 7000 series ICP-OES instrument. For standard measurements, an ICP grade MERCK standard was used. The zeta potentials were determined using dynamic light scattering (DLS) on a Malvern Instruments Zetasizer.

\section{General procedure for the synthesis of water soluble perylene} diimide (LDPI) ${ }^{61-63}$

$1 \mathrm{~g}$ (2.55 mmol) of PTCDA, $1.154 \mathrm{~g}(6.37 \mathrm{mmol}) \mathrm{L}-D O P A$ and $8 \mathrm{~g}$ of imidazole were heated at $130{ }^{\circ} \mathrm{C}$ for $6 \mathrm{~h}$ under an inert atmosphere. Then, $100 \mathrm{~mL}$ of ethanol was poured into the hot mixture, refluxed for $6 \mathrm{~h}$ and left overnight to precipitate out. The precipitate was filtered and washed with ethanol several times. The product was dried at $70{ }^{\circ} \mathrm{C}$ in a vacuum oven to obtain $1.40 \mathrm{~g}$ of a deep dark blackish red solid powder product, with a yield of $71 \%$ (Scheme 1).

${ }^{1} \mathrm{H}-\mathrm{NMR}\left(500 \mathrm{MHz}, \mathrm{D}_{2} \mathrm{O}, 2{ }^{\circ} \mathrm{C}\right)$ d: $8.26(\mathrm{br}, 8 \mathrm{H}), 6.78(\mathrm{~m}, 2 \mathrm{H})$, 6.67 (br, 4H), 5.97 (br, 2H), 5.74 (br, 4H). MS (MALDI-TOF): $m / z$ calc. for $\mathrm{C}_{42} \mathrm{H}_{26} \mathrm{~N}_{2} \mathrm{O}_{12}$ : 750.66, found: $751.12\left[\mathrm{M}+\mathrm{H}^{+}\right]$. FT-IR $(\mathrm{KBr}) \nu_{\max }=630,751,958,1254,1342,1367,1438,1576,1651$, 1693, $3455 \mathrm{~cm}^{-1}$. UV/Vis $\left(\mathrm{H}_{2} \mathrm{O}\right): \lambda_{\max } / \mathrm{nm}\left(\varepsilon / \mathrm{M}^{-1} \mathrm{~cm}^{-1}\right)$ 522 (29627), 486 (17 438), 455 (8795). Fluorescence $\left(\mathrm{H}_{2} \mathrm{O}\right)$ : $\lambda_{\max } / \mathrm{nm}: 569,618$, fluorescence quantum yield $\left(\Phi_{\mathrm{f}}\right)=0.54$.

\section{General procedure for "in situ" synthesis of NPLD-nanoparticles ${ }^{64}$}

The nanomaterial was synthesized following an in situ method, as follows, in a typical reaction, $0.5 \mathrm{~mL}$ of $2 \mathrm{mM}$ LDPI was diluted with $20 \mathrm{~mL}$ of water. $2 \mathrm{~mL}$ of $\mathrm{FeCl}_{3}(20.0 \mathrm{mM})$ and $2 \mathrm{~mL}$

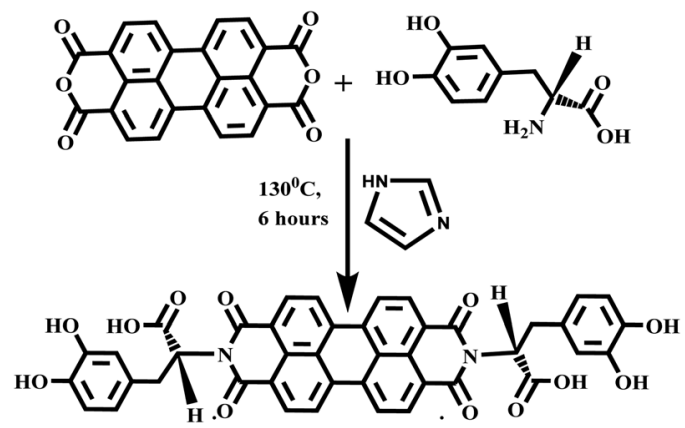

Scheme 1 Diagram showing the synthesis of L-DOPA functionalized perylene diimide (LDPI). of $\mathrm{FeSO}_{4}(25 \mathrm{mM})$ were added dropwise to this solution and the mixture was stirred at room temperature for $30 \mathrm{~min} .0 .3 \mathrm{~mL}$ of ammonia was added to adjust the $\mathrm{pH}$ of the solution to about 10. Subsequently, the mixture was heated to $90{ }^{\circ} \mathrm{C}$ and stirred for $30 \mathrm{~min}$. After the mixture was cooled to room temperature, the resulting precipitate was separated from the suspension by centrifugation (4000 rpm) and washed with water four times, to therefore obtain the nanomaterial (NPLD).

\section{Experimental methods}

Stock solutions for the lead(II) ion, other experimental cations and ethylenediaminetetraacetic acid (EDTA). Different amounts of analytical grade lead(II) chloride $\left(\mathrm{PbCl}_{2}\right)$ were used to prepare stock solutions of various concentrations viz. 200, 500, 1000 and $1300 \mathrm{mg} \mathrm{L}^{-1}$.

For the $200 \mathrm{mg} \mathrm{L^{-1 }} \mathrm{PbCl}_{2}$ solution, $8 \mathrm{mg}$ of $\mathrm{PbCl}_{2}$ was dissolved in $29.8 \mathrm{~mL}$ of HPLC water. Similarly, 15, 35 and $27 \mathrm{mg}$ of $\mathrm{PbCl}_{2}$ were dissolved in 22.38, 20.06 and $20.116 \mathrm{~mL}$ of HPLC water, respectively, using a micropipette in order to produce 500, 1300, and $1000 \mathrm{mg} \mathrm{L}^{-1}$ solutions, respectively, in $50 \mathrm{~mL}$ Falcon tubes. All of the weights were carefully measured using a microbalance.

For the selectivity tests, $10 \mathrm{mg}$ of $\mathrm{Mg}\left(\mathrm{NO}_{3}\right)_{2}$ (magnesium nitrate), $\mathrm{CdSO}_{4} \cdot 8 \mathrm{H}_{2} \mathrm{O}$ (cadmium sulphate), $\mathrm{PbCl}_{2}$ (lead chloride), $\mathrm{Ca}\left(\mathrm{NO}_{3}\right)_{2} \cdot 4 \mathrm{H}_{2} \mathrm{O}$ (calcium nitrate), $\mathrm{ZnCl}_{2}$ (zinc chloride), $\mathrm{NaCl}$ (sodium chloride) and $\mathrm{KCl}$ (potassium chloride) respectively, were carefully weighed in seven different beakers and 47.394, 73.04, 372.527, 84.857, 239.873, 196.695 and 262.228 mL of HPLC water were added, respectively, to make $20 \mathrm{ppm}$ metal stock solutions.

For the breakthrough experiment we have made another series of $7000 \mathrm{ppm}$ stock solutions for all interfering metals and lead(II). $739 \mathrm{mg}$ of $\mathrm{Mg}\left(\mathrm{NO}_{3}\right)_{2}$ (magnesium nitrate), $480 \mathrm{mg}$ of $\mathrm{CdSO}_{4} \cdot 8 \mathrm{H}_{2} \mathrm{O}$ (cadmium sulphate), $94 \mathrm{mg}$ of $\mathrm{PbCl}_{2}$ (lead chloride), $413 \mathrm{mg}$ of $\mathrm{Ca}\left(\mathrm{NO}_{3}\right)_{2} \cdot 4 \mathrm{H}_{2} \mathrm{O}$ (calcium nitrate), $146 \mathrm{mg}$ of $\mathrm{ZnCl}_{2}$ (zinc chloride), $178 \mathrm{mg} \mathrm{NaCl}$ (sodium chloride) and $134 \mathrm{mg}$ of $\mathrm{KCl}$ (potassium chloride) were measured into seven different beakers and $10 \mathrm{~mL}$ of HPLC water was added, respectively, to make 7000 ppm metal stock solutions. $10 \mathrm{~mL}$ solutions containing $140 \mathrm{ppm}$ of each metal ion were prepared individually from the above solutions with the appropriate dilution.

For the regeneration experiments, $100 \mathrm{~mL}$ of $0.01 \mathrm{~mol} \mathrm{~L}^{-1}$ EDTA solution was prepared as a stock solution for regeneration studies by dissolving $372 \mathrm{mg}$ of EDTA in $100 \mathrm{~mL}$ of HPLC water. ICP grade MERCK standard was used for all experiments.

\section{$\mathbf{P b}^{2+}$ adsorption isotherm}

Into three different $15 \mathrm{~mL}$ Falcon tubes was placed $10 \mathrm{mg}$ of NPLD and $5 \mathrm{~mL}$ of HPLC water was added to each. The solutions were dispersed using a sonicating bath and sonicated for $15 \mathrm{~min}$. Finally, $5 \mathrm{~mL}$ of the previously prepared three stock solutions of $\mathrm{Pb}(\mathrm{II}), 200,500$ and $1300 \mathrm{mg} \mathrm{L}^{-1}$, were added separately to each tube to obtain the desired concentrations of lead(II) ions, i.e. 100,250 and $650 \mathrm{mg} \mathrm{L}^{-1}$, respectively.

All of the three final solutions were shaken well to make them homogenous and magnetic pellets of $15 \mathrm{~mm}$ in length 
were added to each solution. They were placed on a magnetic stirrer and stirred at $200 \mathrm{rpm}$ at room temperature for $24 \mathrm{~h}$ to facilitate the adsorption of $\mathrm{Pb}^{2+}$ by NPLD. After $24 \mathrm{~h}$, the magnetic stirrers were switched off and the solutions were allowed to settle down. After $24 \mathrm{~h}$ of adsorption, the $\mathrm{Pb}^{2+}$ coated NPLD settled down at the bottom of the falcon tube towards the magnetic stirrer because of its superparamagnetic nature. To measure the amount of adsorbed $\mathrm{Pb}^{2+}$ ion concentration, $5 \mathrm{~mL}$ of the supernatant was removed from each solution. ICP-OES (inductively coupled plasma-optical emission spectrometry) was performed to measure the $\mathrm{Pb}^{2+}$ concentration.

The samples for the ICP-OES measurements were prepared as follows: each of the $5 \mathrm{~mL}$ supernatant samples was centrifuged at $11000 \mathrm{rpm}$ at room temperature for $10 \mathrm{~min}$, then acidified with $20 \% \mathrm{HNO}_{3}$, then kept in a rocker overnight, again the solution was centrifuged at $11000 \mathrm{rpm}$ at room temperature for $10 \mathrm{~min}$ and filtered using a $60 \mathrm{~mL}$ syringe with an AXIVA $25 \mathrm{~mm} / 0.2 \mu \mathrm{m}$ sterile filter. After filtration, $2.7 \mathrm{~mL}$ of the previously derived $100 \mathrm{mg} \mathrm{L^{-1 }} \mathrm{Pb}^{2+}$ solution, $4 \mathrm{~mL}$ of the $250 \mathrm{mg} \mathrm{L}{ }^{-1} \mathrm{~Pb}^{2+}$ solution and $3.9 \mathrm{~mL}$ of the $650 \mathrm{mg} \mathrm{L}{ }^{-1} \mathrm{~Pb}^{2+}$ solution were placed in three separate $15 \mathrm{~mL}$ falcon tubes and filled with 7.3, 6, and $6.1 \mathrm{~mL}$ of HPLC water, respectively, to reach the minimum volume of $10 \mathrm{~mL}$ to make them eligible for ICP-OES. In a similar way, a blank solution of $1000 \mathrm{mg} \mathrm{L}^{-1}$ of lead(II) solution was prepared and ICP-OES was performed.

$\mathbf{P b}^{2+}$ adsorption kinetics. $10 \mathrm{mg}$ of NPLD was weighed using a microbalance, placed in a $15 \mathrm{~mL}$ Falcon tube and $5 \mathrm{~mL}$ of HPLC water was added to it. The mixture was dispersed using an ultrasonic bath.

$5 \mathrm{~mL}$ of the previously prepared $200 \mathrm{mg} \mathrm{L}^{-1}$ stock solution was taken and added to the $5 \mathrm{~mL}$ NPLD solution while resting on the magnetic stirrer and adding magnetic pellets simultaneously. A stopwatch was started at the contact time and a series of $1 \mathrm{~mL}$ aliquots of the supernatant was taken out at 2, 5, 10, 30 and $60 \mathrm{~min}$ intervals and poured into five different $15 \mathrm{~mL}$ Falcon tubes. $4 \mathrm{~mL}$ of HPLC water was added individually to each of the newly prepared solutions, each of them was centrifuged at $11000 \mathrm{rpm}$ at room temperature for $10 \mathrm{~min}$, then acidified with $20 \% \mathrm{HNO}_{3}$, then kept in a rocker overnight, then again each of the solutions was centrifuged at $11000 \mathrm{rpm}$ at room temperature for $10 \mathrm{~min}$ and filtered using a $60 \mathrm{~mL}$ syringe and an AXIVA $25 \mathrm{~mm} / 0.2 \mu \mathrm{m}$ sterile filter. After filtration, 4, 4, $4.9,4.5$, and $4.6 \mathrm{~mL}$ from the respective five solutions of $\mathrm{Pb}^{2+}$ were placed in five separate $15 \mathrm{~mL}$ Falcon tubes and filled up with $6,6,5.1,5.5$, and $5.4 \mathrm{~mL}$ of HPLC water respectively to reach the minimum volume of $10 \mathrm{~mL}$ to carry out the ICP-OES measurements.

Regeneration study. The NPLD-Pb(II) complex was collected from the solution by magnetic separation, gently washed with HPLC water to remove any unabsorbed metal ions, dried and then weighed using a microbalance. $20 \mathrm{mg}$ of the NPLD-Pb(II) complex was weighed in a Falcon tube. $20 \mathrm{~mL}$ of EDTA solution (0.01 mol $\mathrm{L}^{-1}$ ) was then added to it from the previously prepared EDTA stock solution. The mixture was stirred at $200 \mathrm{rpm}$ at room temperature for $24 \mathrm{~h}$ to allow desorption to take place. After completion, colloidal nanoparticles had settled at the bottom and were collected using magnetic separation. Then, it was dried and weighed and found to be $19 \mathrm{mg}$. It was further mixed with $9.5 \mathrm{~mL}$ HPLC water and $9.5 \mathrm{~mL}$ of the previously prepared $200 \mathrm{mg} \mathrm{L^{-1 }} \mathrm{Pb}^{2+}$ solution. This newly prepared solution was stirred for $24 \mathrm{~h}$ at $200 \mathrm{rpm}$. After $24 \mathrm{~h}$, the NPLD- $\mathrm{Pb}^{2+}$ complex was isolated by magnetic separation and the supernatant solution was centrifuged at $11000 \mathrm{rpm}$ at room temperature for $10 \mathrm{~min}$, then acidified with $20 \% \mathrm{HNO}_{3}$, and kept in a rocker overnight. Again, the solution was centrifuged at $11000 \mathrm{rpm}$ at room temperature for $10 \mathrm{~min}$ and filtered using a $60 \mathrm{~mL}$ syringe and an AXIVA $25 \mathrm{~mm} /$ $0.2 \mu \mathrm{m}$ sterile filter, $4 \mathrm{~mL}$ of the experimental solution was removed and topped up with $6 \mathrm{~mL}$ of HPLC water for the ICP-OES measurements. The entire process was repeated three times by separating and collecting 18, 17 and $16 \mathrm{mg}$ of NPLD nanoparticles consecutively via the aforementioned experiments. $18 \mathrm{mg}$ of the NPLD nanoparticles was dispersed with $9 \mathrm{~mL}$ of HPLC water and $9 \mathrm{~mL}$ of the previously prepared $200 \mathrm{mg} \mathrm{L}^{-1} \mathrm{~Pb}^{2+}$ solution. The recollected $17 \mathrm{mg}$ of NPLD was mixed with $8.5 \mathrm{~mL}$ of HPLC water and $8.5 \mathrm{~mL}$ of the previously prepared $200 \mathrm{mg} \mathrm{L}^{-1} \mathrm{~Pb}^{2+}$ solution and the last $16 \mathrm{mg}$ of recollected NPLD was dissolved in $8 \mathrm{~mL}$ of HPLC water and $8 \mathrm{~mL}$ of the previously prepared $200 \mathrm{mg} \mathrm{L}^{-1} \mathrm{~Pb}^{2+}$ solution.

\section{Selectivity tests}

Selectivity experiments were performed with $\mathrm{Na}^{+}, \mathrm{K}^{+}, \mathrm{Ca}^{2+}, \mathrm{Zn}^{2+}$, $\mathrm{Mg}^{2+}, \mathrm{Cd}^{2+}$, and $\mathrm{Pb}^{2+}$ ions. Firstly, $10 \mathrm{mg}$ of NPLD was placed individually into seven different $15 \mathrm{~mL}$ Falcon tubes using a microbalance, along with $5 \mathrm{~mL}$ of HPLC water using a micropipette. The solutions were dispersed using an ultrasonic bath as described previously. $5 \mathrm{~mL}$ of the previously prepared 20 ppm stock cationic solution of $\mathrm{Na}^{+}, \mathrm{K}^{+}, \mathrm{Ca}^{2+}, \mathrm{Zn}^{2+}, \mathrm{Mg}^{2+}$ and $\mathrm{Cd}^{2+}$ ions were added individually to the seven aforementioned $15 \mathrm{~mL}$ Falcon tubes, respectively. For the preparation of the mixed cationic solution for the breakthrough experiment, $715 \mu \mathrm{L}$ of each cationic solution of the previously prepared $140 \mathrm{ppm}$ stock solution was added to a $5 \mathrm{~mL}$ aqueous solution containing the dispersed $10 \mathrm{mg}$ NPLD nanomaterial to give a total volume of $10 \mathrm{~mL}$. The final concentration of all metal ions was $10 \mathrm{ppm}$. In addition, $715 \mu \mathrm{L}$ of each of the other six cations, other than lead, of the previously prepared 7000 ppm stock solution, and $715 \mu \mathrm{L}$ of $140 \mathrm{ppm} \mathrm{Pb}$ (II) were added to another $5 \mathrm{~mL}$ aqueous solution containing the dispersed $10 \mathrm{mg}$ NPLD nanomaterial to give a total volume of $10 \mathrm{~mL}$. The final concentration of all cations, except for lead(II), was 500 ppm and the final concentration of lead(II) was $10 \mathrm{ppm}$ in this solution. All of the final solutions were shaken well to ensure homogeneity and magnetic pellets of $15 \mathrm{~mm}$ length were added into each solution. They were placed on a magnetic stirrer and stirred at $200 \mathrm{rpm}$ at room temperature for $24 \mathrm{~h}$ to facilitate the adsorption of cations by NPLD. After completion, the colloidal nanoparticles were allowed to settle and were removed using magnetic separation, $5 \mathrm{~mL}$ of the supernatant solution was taken from each and $5 \mathrm{~mL}$ of HPLC water was added individually to all the solutions giving a total volume of $10 \mathrm{~mL}$. The solutions were then centrifuged at $11000 \mathrm{rpm}$ at room temperature for $10 \mathrm{~min}$, 
no particles were observed, then they were acidified using $20 \%$ $\mathrm{HNO}_{3}$, then kept in a rocker overnight, the solutions were again centrifuged at $11000 \mathrm{rpm}$ at room temperature for $10 \mathrm{~min}$ and filtered using a $60 \mathrm{~mL}$ syringe and an AXIVA $25 \mathrm{~mm} / 0.2 \mu \mathrm{m}$ sterile filter. Finally, $10 \mathrm{~mL}$ of each of the experimental solutions was used for ICP-OES measurements. A blank metal solution of $10 \mathrm{ppm}$ was prepared using the same procedure used in the ICP-OES process.

pH dependence. In each of the three separate $15 \mathrm{~mL}$ Falcon tubes, $10 \mathrm{mg}$ of NPLD was added and volume was maintained to $5 \mathrm{~mL}$ of aqueous solution using HPLC water, the $\mathrm{pH}$ was adjusted to 2, 5 and 8 . Then, $5 \mathrm{~mL}$ of the $20 \mathrm{ppm}$ lead(II) stock solution was added into each of them and made homogenous, they were then stirred with a magnetic stirrer at $200 \mathrm{rpm}$ for $24 \mathrm{~h}$. After completion, the colloidal nanoparticles were allowed to settle and were removed by magnetic separation, $5 \mathrm{~mL}$ of the supernatant solution was taken from each and $5 \mathrm{~mL}$ of HPLC water was added individually to all of the solutions making the total volume at $10 \mathrm{~mL}$, then the solutions were centrifuged at $11000 \mathrm{rpm}$ at room temperature for $10 \mathrm{~min}$, no particles were observed. They were then acidified with $20 \% \mathrm{HNO}_{3}$, kept in rockers for $12 \mathrm{~h}$, the solutions were again centrifuged at $11000 \mathrm{rpm}$ at room temperature for $10 \mathrm{~min}$ and filtered using a $60 \mathrm{~mL}$ syringe and an AXIVA $25 \mathrm{~mm} / 0.2 \mu \mathrm{m}$ sterile filter and $10 \mathrm{~mL}$ of each of the experimental solutions was used for ICP-OES measurements.

\section{Cell culture}

WI38 cells were cultured in the lab supplemented with a $5 \% \mathrm{CO}_{2}$ humidified atmosphere at $37{ }^{\circ} \mathrm{C}$ using Dulbecco's modified eagle's medium (DMEM) containing 10\% fetal bovine serum, kanamycin sulfate $\left(110 \mathrm{mg} \mathrm{L}^{-1}\right)$, penicillin (50 units per $\mathrm{mL}$ ), and streptomycin $\left(50 \mu \mathrm{g} \mathrm{mL}{ }^{-1}\right)$, trypsin-EDTA $(1 \times)$ solution was used for cell splitting.

\section{Cell viability assay}

WI38 cells were treated with the NPLD and an MTT assay was performed to check the cellular viability. The MTT assay is a colorimetric analysis in which MTT is reduced to purple formazan using cellular reductase enzymes of live cells. Dead cells do not produce cellular reductase, and hence are unable to develop the purple color. Therefore, the number of dead cells can be quantitatively estimated from the absorbance study. Using this phenomenon, we checked the number of cells that were alive after treatment with NPLD with respect to cells (control) which were not treated with the compound. The $Y$-axis of the bar plot represents the \% viability of cells (the percentage of live cells compared to the control) and the $X$-axis represents the various concentrations of NPLD. The absorbance at $550 \mathrm{~nm}$ was measured using the Multiskan ${ }^{\mathrm{TM}}$ GO Microplate Spectrophotometer and the \% viability was calculated. Cells were seeded at a density of 10000 cells per well in a 96-well plate before $24 \mathrm{~h}$ of treatment. Cells were treated with 3.125, $6.25,12.5$, and $25 \mu \mathrm{g} \mathrm{mL}{ }^{-1}$ solutions of NPLD in serum free media for $4 \mathrm{~h}$. After that the cells were incubated for $48 \mathrm{~h}$ in complete media. The MTT solution $\left(5 \mathrm{mg} \mathrm{mL}^{-1}\right)$ was prepared in PBS. $50 \mu \mathrm{L}$ of MTT solution was added into each well and incubated at $37{ }^{\circ} \mathrm{C}$ for $4 \mathrm{~h}$. Purple colored formazan was dissolved in 1:1 (v/v) DMSO/MeOH and the absorbance of the wells was measured at $550 \mathrm{~nm}$ using a micro-plate ELISA reader. The \% viability was calculated from these absorbance values. The data show that the \% viability remains over $90 \%$ upon increasing the concentration of NPLD.

\section{Result and discussion}

A schematic illustration for the construction of the perylene diimide coated magnetic nanoparticle (NPLD) and its application for the removal of lead(II) from water is shown in Fig. 1, in which LDPI was formed by reacting L-DOPA with PTCDA. The LDPI was synthesized following the previous report, ${ }^{61-63}$ using imidazole as a solvent. The LDPI coated nanoparticles were synthesized using the "in situ" $\operatorname{method}^{64}$ to obtain a reddish black powder that exhibits a magnetic response in the presence of an external magnet. It showed an exceptional stability of more than 6 years in a dry state as its dispersibility in water and the magnetic response remains the same, with dopamine outside, which is strongly susceptible to $\mathrm{Pb}(\mathrm{II}) .{ }^{65}$ To corroborate the presence of the desired functional groups, FTIR spectroscopy was performed for pure LDPI, as well as NPLD. The infrared spectra were measured in the range $4000-400 \mathrm{~cm}^{-1}$. Table 1 shows the FTIR data ${ }^{65,66}$ and Fig. 2 a shows the peaks in the FTIR spectra. As shown in Fig. 2a, the six characteristic major bands corresponding to the functional groups $-\mathrm{O}-\mathrm{H}$ stretching ( $-\mathrm{COOH}$ group), $-\mathrm{C}=\mathrm{O}$ stretching $(-\mathrm{COOH}$ group and imide group), $-\mathrm{C}-\mathrm{O}$ stretching ( $-\mathrm{COOH}$ group) and $-\mathrm{O}-\mathrm{H}$ bending (-COOH group), were analyzed for both LDPI and NPLD, which are summarized in Table 1 . The shifting of the major bands towards a lower frequency region indicates the formation of conjugated nanomaterials, as - $\mathrm{O}-\mathrm{H}$ groups and oxygen of the carbonyl groups are interacting with iron oxide, and hence the subsequent bond order decreases. ${ }^{64}$ The peaks at 567 and $429 \mathrm{~cm}^{-1}$ correspond to the vibration of the tetrahedral and octahedral site of $\mathrm{Fe}^{3+} / \mathrm{Fe}^{2+}-\mathrm{O}^{2-} \cdot{ }^{62}$ X-ray diffraction (XRD) was performed to analyze the crystalline orientation of the magnetic core, $\mathrm{Fe}_{3} \mathrm{O}_{4}$. The six characteristic peaks of $\mathrm{Fe}_{3} \mathrm{O}_{4}{ }^{67}$ were found in Fig. $2 b$ at $0.485,0.298,0.253,0.210,0.171,0.161$ and $0.148 \mathrm{~nm}$ which give the corresponding characteristic planes (111), (220), (311), (400), (422), (511) and (440) of the cubic inverse spinel $\mathrm{Fe}_{3} \mathrm{O}_{4}$ structure ${ }^{68,69}$ further supporting the structure of the NPLD nanomaterial.

High-resolution transmission electron microscopy revealed the morphological state of the NPLD-magnetic core, which has a cloud-like periphery encircling a black nexus with prominent crystal planes. In this context, as shown in Fig. 3a, the image shows no agglomerated structure and the cloud-like periphery represents the shell of the aggregated perylene diimide molecules via coordination bonding induced by the hydroxyl group and the $-\mathrm{COOH}$ group present at the imide position on the magnetic core. The core is depicted as the black nexus of $\mathrm{Fe}_{3} \mathrm{O}_{4}$, as clearly shown in Fig. $3 \mathrm{~b}$ and c. Fig. $3 \mathrm{a}$ and $\mathrm{b}$ reveals the 

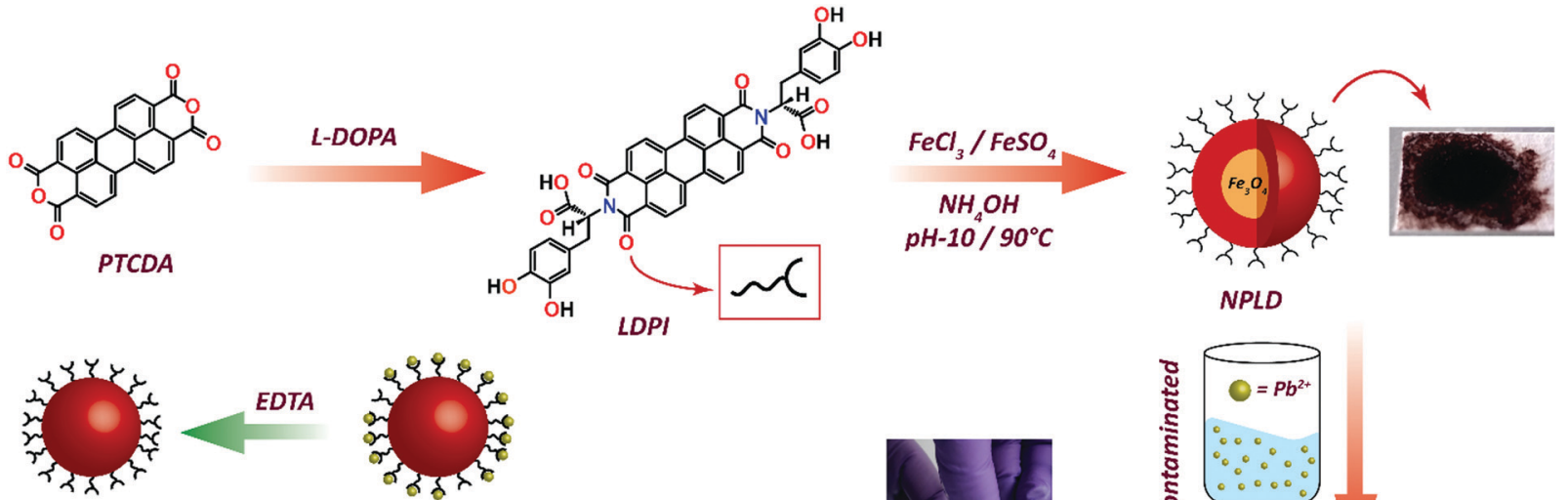

Recovered

nanoparticle

$\mathrm{Pb}^{2+}$

adsorbed nanoparticle
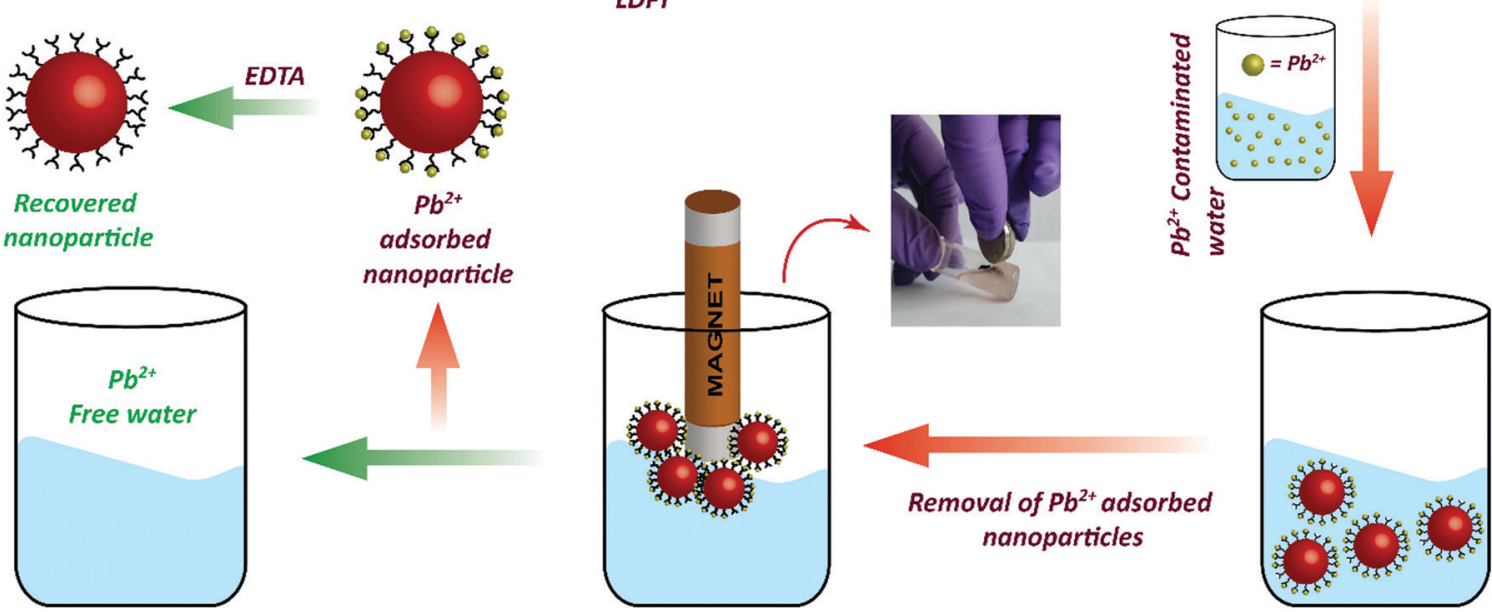

Fig. 1 Schematic illustration of the synthesis of perylene diimide coated magnetic nanoparticles (NPLD) and its application for the removal of $\mathrm{Pb}^{2+}$ ions from contaminated water.

\section{Table 1 Comparison of FTIR data for pure LDPI and NPLD nanomaterials}

\begin{tabular}{lll}
\hline Peak assigned for bands & LDPI $\left(\mathrm{cm}^{-1}\right)$ & NPLD $\left(\mathrm{cm}^{-1}\right)$ \\
\hline (1) -O-H stretching (-COOH group) & $3455-2830$ & $3452-2832$ \\
(2) -C=O stretching (-COOH group) & 1693 & 1686 \\
(3) -C=O stretching (imide group) & 1651 & 1643 \\
(4) -O-H bending (-COOH group) & 1438 & 1401 \\
(5) -C-O stretching (-COOH group) & 1342 & 1342
\end{tabular}

formation of 20-30 nm sized core-shell nanoparticles. Fig. 3b and $\mathrm{c}$ provides information about the size of the core and the shell of the NPLD nanoparticles, which are 21-26 and 4-6 nm respectively. Energy dispersive X-ray analysis (EDX) proved ${ }^{65}$ the presence of iron with a typical iron peak value of 6.4, as shown in Fig. 3d. The superparamagnetic nature of the inverse spinel magnetite was confirmed by using a cryogenic physical property measurement system superconducting quantum interference device (SQUID) magnetometer. ${ }^{70,71}$ The hysteresis curve obtained, as shown in Fig. 4a reveals that they are superparamagnetic at room temperature and exhibit a narrow hysteresis loop at $4 \mathrm{~K}$ with a coercivity of $215 \mathrm{Oe}$, which indicates a reversible magnetization-demagnetization nature. (a)

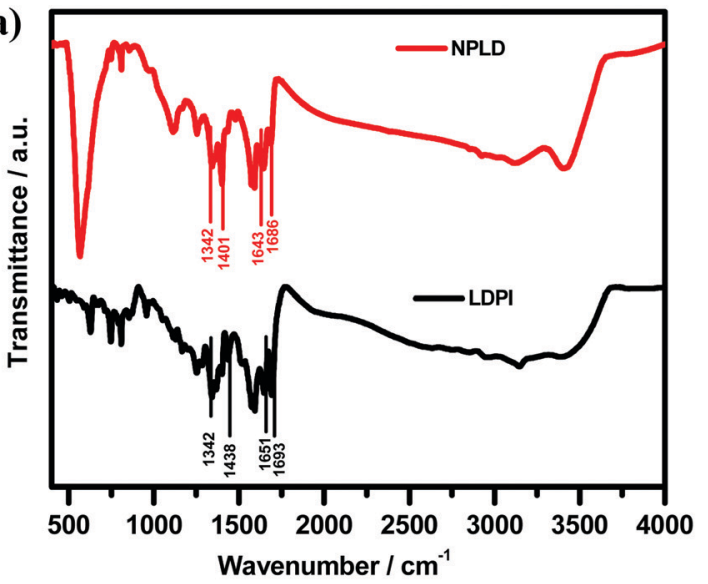

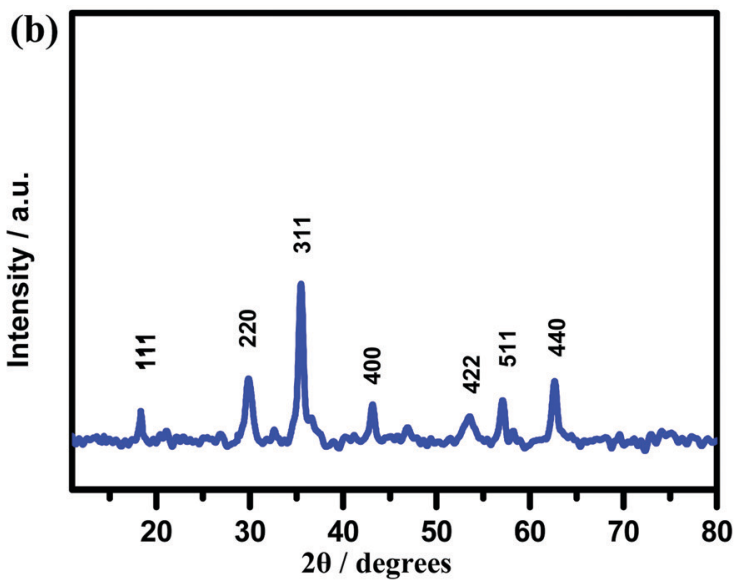

Fig. 2 (a) FTIR of NPLD and pure LDPI. (b) XRD pattern of NPLD, showing the distinct plane (111), (220), (311), (400), (422), (511) and (440) of the cubic inverse spinel $\mathrm{Fe}_{3} \mathrm{O}_{4}$ structure (JCPDS number-19-0629). 

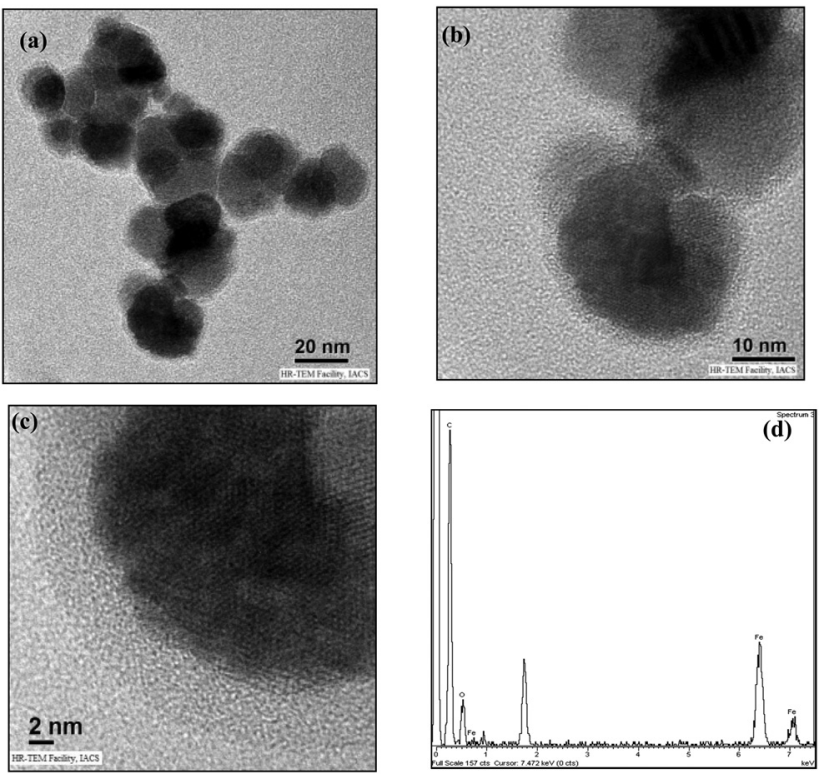

Fig. 3 (a-c) Show low to high resolution HRTEM images of NPLD nanoparticles. (a) The nanoparticles are not agglomerated, from (b) the size is determined to be $24 \mathrm{~nm}$ and (c) clearly shows the dark magnetic iron oxide core encircled by an aggregated L-DOPA functionalized perylene diimide (shell). (d) EDX showing characteristic peaks of Fe present in NPLD.

The saturation magnetization value is $\sim 8.5 \mathrm{emu} \mathrm{g}^{-1}$ at $300 \mathrm{~K}$. The zero-field cooled (ZFC) and field cooled (FC) magnetization curves shown in Fig. 4 b exhibit a distinct blocking temperature of $130 \mathrm{~K}$ (measured at $100 \mathrm{Oe}$ ), which is also characteristic of superparamagnetism. The superparamagnetic characteristic of the magnetic iron core of NPLD is responsible for the attraction to the external magnetic field, which is the key feature of separating lead from lead-contaminated water.

The latest literature surveys portrayed different organic compounds with distinct chelating ligands showing their capabilities for the removal of heavy metals such as. $\mathrm{Pb}^{2+}$, $\mathrm{Hg}^{2+}, \mathrm{Cd}^{2+}, \mathrm{Cu}^{2+}$ and so forth ${ }^{42,43,46,70,72}$ from water. Yu and co-workers $^{42}$ developed a three dimensional porous MOF $\left\{\left[\mathrm{Zn}_{3} \mathrm{~L}_{3}(\mathrm{BPE})_{1.5}\right] \cdot 4.5 \mathrm{DMF}\right\}_{n}\left(1, \mathrm{H}_{2} \mathrm{~L}=4,4^{\prime}\right.$-azoxydibenzoic 5 acid, $\mathrm{BPE}=$ bis(4-pyridyl)ethylene, $\mathrm{DMF}=N, N$-dimethylformamide) functionalized with $\mathrm{O}^{-}$groups in which oxygen showed $99.27 \%$ significant binding with $\mathrm{Pb}^{2+}$ ions and $17.46 \%$ for cadmium adsorption. The maximum lead(II) adsorption was $616.64 \mathrm{mg} \mathrm{g}^{-1}$ owing to the strong electrostatic interaction between them, the activated negatively charged oxygen formed co-ordination bonds with lead. Also, being a Lewis acid, $\mathrm{Pb}^{2+}$ has a large ionic radius along with a low hydration energy which facilitates the formation of the acid-base adduct with the Lewis base $\mathrm{O}^{-}$. Monier and Abdel-Latif reported a cross-linked magnetic chitosan-phenylthiourea resin for the adsorption of $\mathrm{Hg}$ (II), $\mathrm{Cd}$ (II) and $\mathrm{Zn}$ (II) ions from aqueous solutions of $135 \pm 3,120 \pm 1$ and $52 \pm 1 \mathrm{mg} \mathrm{g}^{-1}$ respectively. ${ }^{70}$ Sun et al. also made MOFs using a polydopamine composite which proved to have a strong affinity to the dopamine ligand for $\mathrm{Pb}^{2+}$ and $\mathrm{Hg}^{2+}$ ions with an adsorption capacity of 394 and $1634 \mathrm{mg} \mathrm{g}^{-1}$ respectively, ${ }^{43}$ however, these MOFs face purification issues after use. Again, Charpentier et al. succeeded in heavy metal removal using magnetic chitosan (CS) and carboxymethylchitosan (CMC) nanocomposites with an adsorption capacity for lead(II), copper(II), and zinc(II) of 243, 232 and $131 \mathrm{mg} \mathrm{g}^{-1}$ respectively. ${ }^{46}$ These literature surveys $^{42,43,46,56,73,74}$ reveal that the $-\mathrm{OH}$ or $-\mathrm{COOH}$ functionality can bind lead ions in water. Keeping that in mind, we were interested to apply our material, NPLD, for $\mathrm{Pb}(\mathrm{II})$ removal. NPLD remarkably reduced the amount of lead ions $\left(\mathrm{Pb}^{2+}\right)$ from 4000 to $7 \mathrm{ppb}$, which is below the permissible limit $\left(10 \mu \mathrm{g} \mathrm{L}^{-1}\right)$ set by the WHO. This excellent preliminary result was encouraged us to quantify the actual $\mathrm{Pb}^{2+}$ adsorption efficiency using our materials. Hence, we have explored the adsorption isotherm study to assess and quantify the effectiveness of NPLD for removing lead from water by varying the concentration of $\mathrm{Pb}^{2+}$ from 100 to $650 \mathrm{mg} \mathrm{L}{ }^{-1}$ with the help of ICP-OES. The $q_{\mathrm{e}}$ (equilibrium adsorption capacity) increased upon increasing the concentration of $\mathrm{Pb}^{2+}$ (Fig. 5). Langmuir models fitted the experimental isotherm equilibrium data with a high correlation coefficient of 0.9927 (Fig. 6). These values gave the best fit for (a)

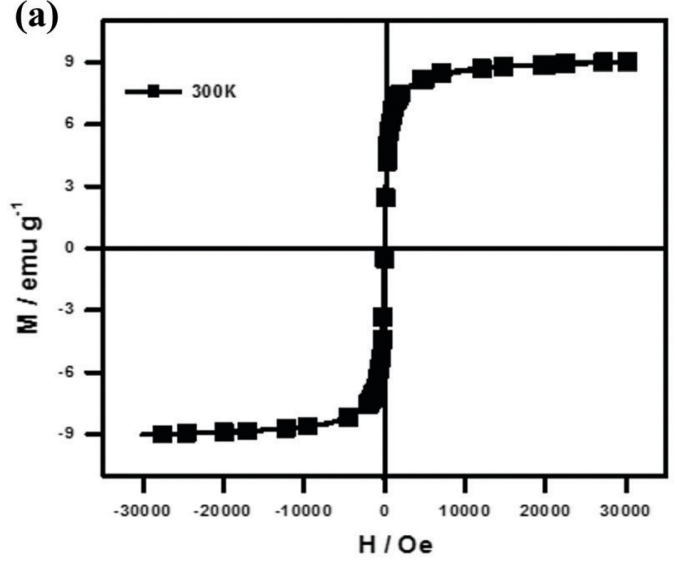

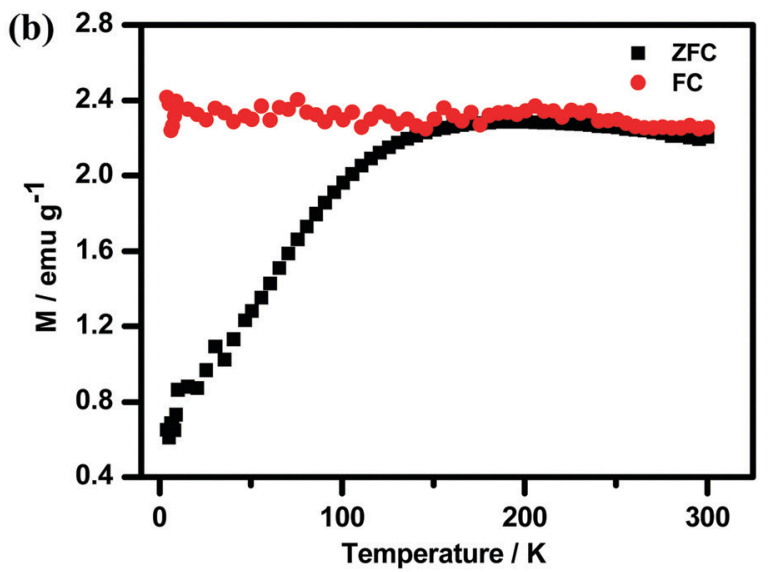

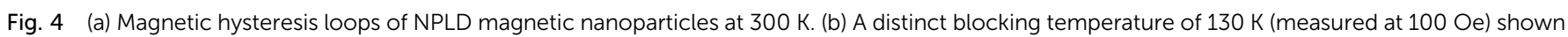
by ZFC and FC magnetization curves. 


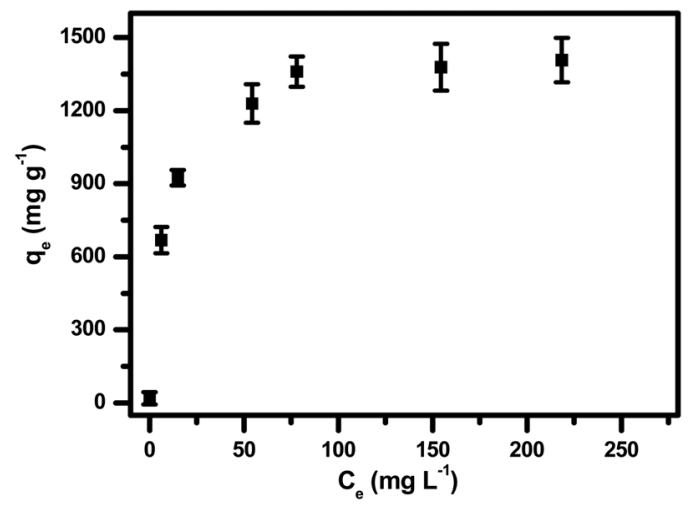

Fig. 5 Adsorption isotherms of $\mathrm{Pb}(॥)$, in which $q_{\mathrm{e}}$ and $C_{\mathrm{e}}$ represent the amount of adsorbed $\mathrm{Pb}^{2+}\left(\mathrm{mg} \mathrm{g}^{-1}\right)$ and the $\mathrm{Pb}(\mathrm{I})$ concentration in solution ( $\mathrm{mg} \mathrm{L}^{-1}$ ) at equilibrium. The value of $q_{\mathrm{e}}$ increased with the increasing amount of $\mathrm{Pb}^{2+}$

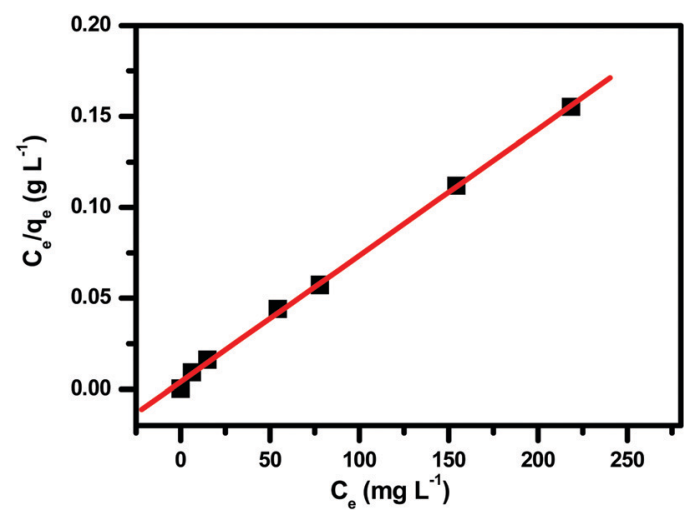

Fig. 6 Langmuir adsorption fitting for the adsorption of $\mathrm{Pb}^{2+}$ by NPLD.

the experimental data of the NPLD magnetic nanoparticles in the entire range of concentrations of $\mathrm{Pb}^{2+}$ that were studied. According to the Langmuir model, the adsorbent surface has a finite number of binding sites of identical energy and each adsorbate ion is located at a single site. The maximum adsorption capacity was calculated to be $1407.5 \mathrm{mg} \mathrm{g}^{-1}$ using the following equation. ${ }^{42}$

$$
q_{t}=\frac{\left(C_{\mathrm{i}}-C_{t}\right) V}{m}
$$

In which, $C_{\mathrm{i}}\left(\mathrm{mg} \mathrm{L}^{-1}\right)$ is the initial $\mathrm{Pb}^{2+}$ concentration and $C_{t}$ $\left(\mathrm{mg} \mathrm{L}^{-1}\right)$ is the $\mathrm{Pb}^{2+}$ ion concentration at time $t(\mathrm{~min}), V$ is the volume of the experimental solution (L) and $m$ is the dry mass (g) of the adsorbent.

Next, it was needed to determine how fast NPLD can take up $\mathrm{Pb}^{2+}$ from water and therefore we have performed a kinetic adsorption study ${ }^{75-77}$ for $\mathrm{Pb}$ (II). To determine the effectiveness of the NPLD nanomaterial for adsorbing lead with time, a kinetic adsorption isotherm of $\mathrm{Pb}$ (II) on NPLD was acquired using $\mathrm{PbCl}_{2}$ solution, in which the concentration of $\mathrm{Pb}^{2+}$ was $100 \mathrm{mg} \mathrm{L}^{-1}$.

The incredibly fast uptake of lead ions by NPLD within 30 min of contact time, as represented in Fig. 7, shows the

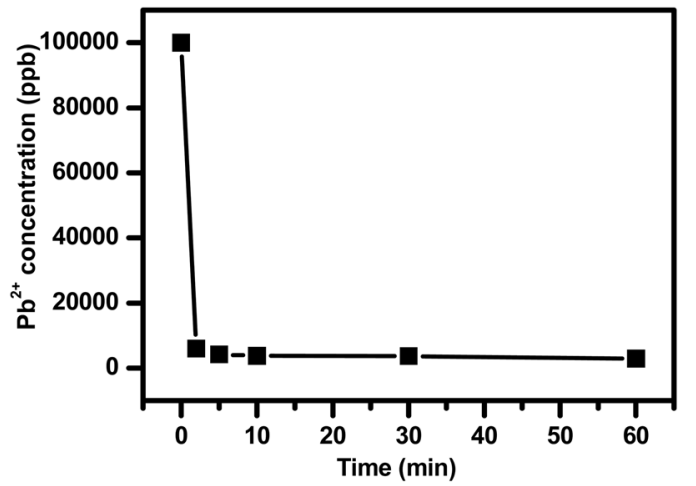

Fig. 7 The kinetic adsorption study of the NPLD nanoparticles was measured, in which NPLD was $10 \mathrm{mg}$ for a $10 \mathrm{~mL} \mathrm{~Pb}^{2+}$ solution having an initial concentration of $100 \mathrm{mg} \mathrm{L}^{-1}$ at room temperature. The graph shows that more than $90 \%$ of lead ions were adsorbed within $10 \mathrm{~min}$ and it reaches equilibrium within $30 \mathrm{~min}$.

reduction from 100 to $3.675 \mathrm{ppm}$, which sets a new benchmark in the series of previously reported adsorbents, indicating its high surface area for adsorption. The unit measure of the affinity of a sorbent for a specific metal ion is the distribution coefficient $\left(K_{\mathrm{d}}\right)$ measurement: ${ }^{42,43,75-81}$

$$
K_{\mathrm{d}}=\frac{C_{\mathrm{i}}-C_{\mathrm{f}}}{C_{\mathrm{f}}} \times \frac{V}{m}
$$

where, $C_{\mathrm{i}}\left(\mathrm{mg} \mathrm{L}^{-1}\right)$ and $C_{\mathrm{f}}\left(\mathrm{mg} \mathrm{L}^{-1}\right)$ represent the initial ion and the final equilibrium metal ion concentrations, respectively, $V$ is the volume of the experimental solution $(\mathrm{mL})$ and $m$ is the mass of the adsorbent which is used. Generally, $K_{\mathrm{d}}$ values that are higher than $10^{4} \mathrm{~mL} \mathrm{~g}^{-1}$ or $\mathrm{L} \mathrm{kg}^{-1}$ are considered as excellent adsorbing materials, ${ }^{42,43,75-78}$ and for our material the value is $1.14 \times 10^{6} \mathrm{~mL} \mathrm{~g}^{-1}$ which surpasses other reported lead removing superparamagnetic adsorbent materials. Table 2 presents a clear comparison of the adsorption uptake with other related reported adsorbing materials.

Owing to the very high distribution coefficient and adsorption capacity of lead ions, we were interested in studying its selectivity among the alkaline earth metals and other coordination metals. Common cations such as $\mathrm{Na}^{+}, \mathrm{K}^{+}, \mathrm{Mg}^{2+}$ and $\mathrm{Ca}^{2+}$ exist ubiquitously in aquatic environments and may undergo competitive adsorption with $\mathrm{Pb}^{2+}$. Hence, a selective adsorption experiment was performed in the presence of $\mathrm{Na}^{+}, \mathrm{K}^{+}, \mathrm{Mg}^{2+}$, $\mathrm{Cd}^{2+}, \mathrm{Zn}^{2+}$ and $\mathrm{Ca}^{2+}$ with concentrations of $10 \mathrm{ppm}$ for each metal ion. ${ }^{42,43}$ The results showed that the adsorption ability of NPLD was exceptionally higher for $\mathrm{Pb}^{2+}$ compared to other metal ions, and to some extent for $\mathrm{Cd}^{2+}$. In the presence of mixed $\left(\mathrm{Na}^{+}, \mathrm{K}^{+}, \mathrm{Mg}^{2+}, \mathrm{Cd}^{2+}, \mathrm{Zn}^{2+}\right.$ and $\left.\mathrm{Ca}^{2+}\right)$ ions, $99.27 \%$ of $\mathrm{Pb}^{2+}$ was removed, whereas, $24.68 \%$ of $\mathrm{Cd}^{2+}$ was removed. In contrast, other metal ions, except for lead and cadmium, had a removal efficiency below $10 \%$, as observed in Fig. 8a owing to their reduced electrostatic attraction with the NPLD magnetic nanoparticle. Common cations such $\mathrm{Na}^{+}, \mathrm{K}^{+}, \mathrm{Mg}^{2+}$ and $\mathrm{Ca}^{2+}$ that are present at a high concentration might lead to competitive adsorption with the $\mathrm{Pb}^{2+}$ ion, we have carried out a competitive experiment with molar ratios of $\mathrm{Na}^{+} / \mathrm{Pb}^{2+}, \mathrm{K}^{+} / \mathrm{Pb}^{2+}, \mathrm{Ca}^{2+} / \mathrm{Pb}^{2+}, \mathrm{Mg}^{2+} / \mathrm{Pb}^{2+}$, 
Table 2 Maximum adsorption capacity and distribution coefficient $\left(K_{\mathrm{d}}\right)$ in comparison to previously published work

\begin{tabular}{|c|c|c|c|c|}
\hline Entry & Adsorbent material & $\begin{array}{l}\text { Adsorption capacity } \\
\left(\mathrm{mg} \mathrm{g}^{-1}\right) \text { of } \mathrm{Pb}^{2+}\end{array}$ & $\begin{array}{l}\text { Distribution } \\
\text { coefficient }\left(K_{\mathrm{d}}\right)\end{array}$ & Reference \\
\hline 1 & CS and CMC magnetite nanoparticles & 243 & Not reported & 46 \\
\hline 2 & $\mathrm{Fe}_{3} \mathrm{O}_{4}-\mathrm{SO}_{3} \mathrm{H}$ MNPs & 108.93 & Not reported & 48 \\
\hline 3 & $\mathrm{Fe}_{3} \mathrm{O}_{4} @ \mathrm{GA}-\mathrm{AAm}$ & 158.73 & Not reported & 77 \\
\hline 4 & $\mathrm{~L}-\mathrm{Cys}-\mathrm{Fe}_{3} \mathrm{O}_{4} \mathrm{NPs}$ & 18.8 & Not reported & 50 \\
\hline 5 & MIL-101(Fe)/GO & 128.6 & Not reported & 78 \\
\hline 6 & $\begin{array}{l}\text { Three-dimensional (3D) porous framework }\left\{\left[\mathrm{Zn}_{3} \mathrm{~L}_{3}(\mathrm{BPE}) 1.5\right] \cdot 4.5 \mathrm{DMF}\right\}_{n} \\
\text { functionalized with } \mathrm{O}-\end{array}$ & 616.64 & $2.3 \times 10^{6} \mathrm{~mL} \mathrm{~g}^{-1}$ & 42 \\
\hline 7 & Graphene oxide- $\mathrm{MnFe}_{2} \mathrm{O}_{4}$ magnetic nanohybrids & 673 & Not reported & 49 \\
\hline 8 & $\mathrm{MoS}_{4}-\mathrm{LDH}$ & 290 & Not reported & 79 \\
\hline 9 & EDTA/chitosan/PMMS & 210 & Not reported & 80 \\
\hline 10 & Fe-BTC/PDA MOF & 394 & $1.7 \times 10^{6} \mathrm{~mL} \mathrm{~g}^{-1}$ & 43 \\
\hline 11 & NPLD & 1407.5 & $1.14 \times 10^{6} \mathrm{~mL} \mathrm{~g}^{-1}$ & This work \\
\hline
\end{tabular}

(a)

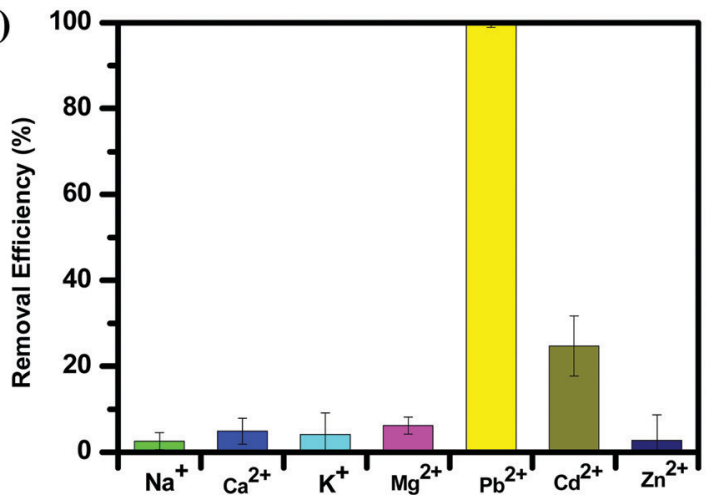

(b)

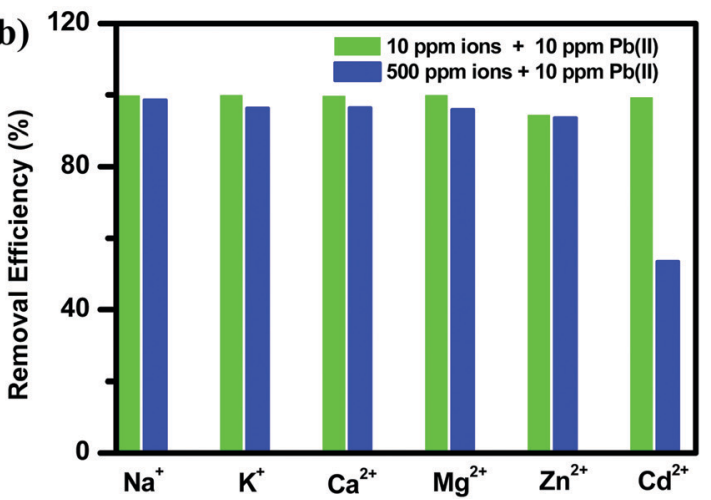

Fig. 8 (a) Response of other coexisting different metal ions on the removal of $\mathrm{Pb}^{2+}$ ions, measured using ICP-OES. (b) The effects of competing ions on the $\mathrm{Pb}^{2+}$ adsorption by NPLD ( $\mathrm{Pb}^{2+}$ concentration: $10 \mathrm{ppm}$; mixed ions concentration: a mixed solution containing $\mathrm{Na}^{+}, \mathrm{K}^{+}, \mathrm{Ca}^{2+}, \mathrm{Mg}^{2+}, \mathrm{Zn}^{2+}$ and $\mathrm{Cd}^{2+}$ with concentrations of $10 \mathrm{ppm}$ and $500 \mathrm{ppm}$ for each ion).

$\mathrm{Zn}^{2+} / \mathrm{Pb}^{2+}$, and $\mathrm{Cd}^{2+} / \mathrm{Pb}^{2+}$ at 1 and 50 (Fig. 8b). There was a minor decrease for $\mathrm{Pb}^{2+}$ removal efficiencies, changing from $99.83 \%$ to $96.27 \%$ with $\mathrm{Na}^{+}, 99.63 \%$ to $96.38 \%$ with $\mathrm{K}^{+}, 99.76 \%$ to $95.81 \%$ with $\mathrm{Ca}^{2+}, 94.28 \%$ to $93.6 \%$ with $\mathrm{Mg}^{2+}$ and $94.28 \%$ to $93.6 \%$ with $\mathrm{Zn}^{2+}$. Removal efficiency was excellent when the molar ratio of $\mathrm{Cd}^{2+} / \mathrm{Pb}^{2+}$ was 1 . When it was 50 , the removal efficiency decreased to $53.42 \%$. In a natural water environment, it is rare to find a high concentration of $\mathrm{Cd}^{2+}$. Therefore, the effect on the removal efficiency of $\mathrm{Pb}^{2+}$ by $\mathrm{Cd}^{2+}$ can be neglected for practical applications. This selectivity can be explained by the hard and soft (Lewis) acids and bases (HSAB) principle. ${ }^{42,81-83} \mathrm{~Pb}^{2+}$ is a borderline acid, whereas oxygen is a borderline base, hence interaction between them is very much compatible. $\mathrm{Cd}^{2+}$ is a soft acid and hence binds to oxygen to some extent, but hard acids such as $\mathrm{Mg}^{2+}, \mathrm{Zn}^{2+}$, and $\mathrm{Ca}^{2+}$ do not bind with oxygen owing to the less efficient pairing. The alkaline earth metal does not quite bind with NPLD. Soft $\mathrm{Cd}^{2+}$ has a comparable size and charge distribution and hence shows some amount of selectivity towards NPLD. The outstanding adsorption of $\mathrm{Pb}^{2+}$ by NPLD is a result of the electrostatic interaction, which is further supported by the zeta potential. ${ }^{42,60}$ The zeta potential of NPLD- $\mathrm{Pb}^{2+}$ is less negative in comparison to bare NPLD (Fig. S1, ESI $\dagger$ ).

The removal of lead can be detected by the naked eye if its concentration remains high in water. When an aqueous
Solution of $\mathrm{Na}_{2} \mathrm{~S}$ was added to water containing $\mathrm{Pb}^{2+}$, the color immediately changed blackish owing to the formation of $\mathrm{PbS}$, which enables us to confirm the presence or absence of lead(II) without any ICP measurement. We have also carried out the same experiment to track lead separation from water by treating lead contaminated water with NPLD. Fig. 9a shows the aqueous solution of $\mathrm{Pb}$ (II) just after dispersion of NPLD with different concentrations of $\mathrm{Pb}^{2+}$ ranging from high to low. Fig. 9b shows the solution after stirring for $30 \mathrm{~min}$ and then allowing to settle. It has been observed that after stirring with NPLD, the concentrated solution appeared to be clear, whereas excess NPLD remains visibly dispersed in the less concentrated solution of $\mathrm{Pb}^{2+}$, proving the effective binding of the nanoparticle with lead(II). This is because NPLD- $\mathrm{Pb}^{2+}$ complex gets heavier in case of high concentration of $\mathrm{Pb}^{2+}$ and is therefore settle down quickly in the presence of a magnetic bar. Now the same amount of $\mathrm{Na}_{2} \mathrm{~S}$ solution was added to the same amount of the two solutions (one before treatment with NPLD and another after treatment with NPLD). The pure $\mathrm{Pb}^{2+}$ solution gave an instant black precipitate of lead sulphide, whereas the NPLD treated solution remained clear proving the reduction of the concentration of the $\mathrm{Pb}^{2+}$ ion using NPLD, as exhibited in Fig. 9c. We have further investigated the influence of $\mathrm{pH}$ on the adsorption and found that NPLD gave a fine adsorption of $\mathrm{Pb}^{2+}$ even at a very low $\mathrm{pH}(2)$ and 

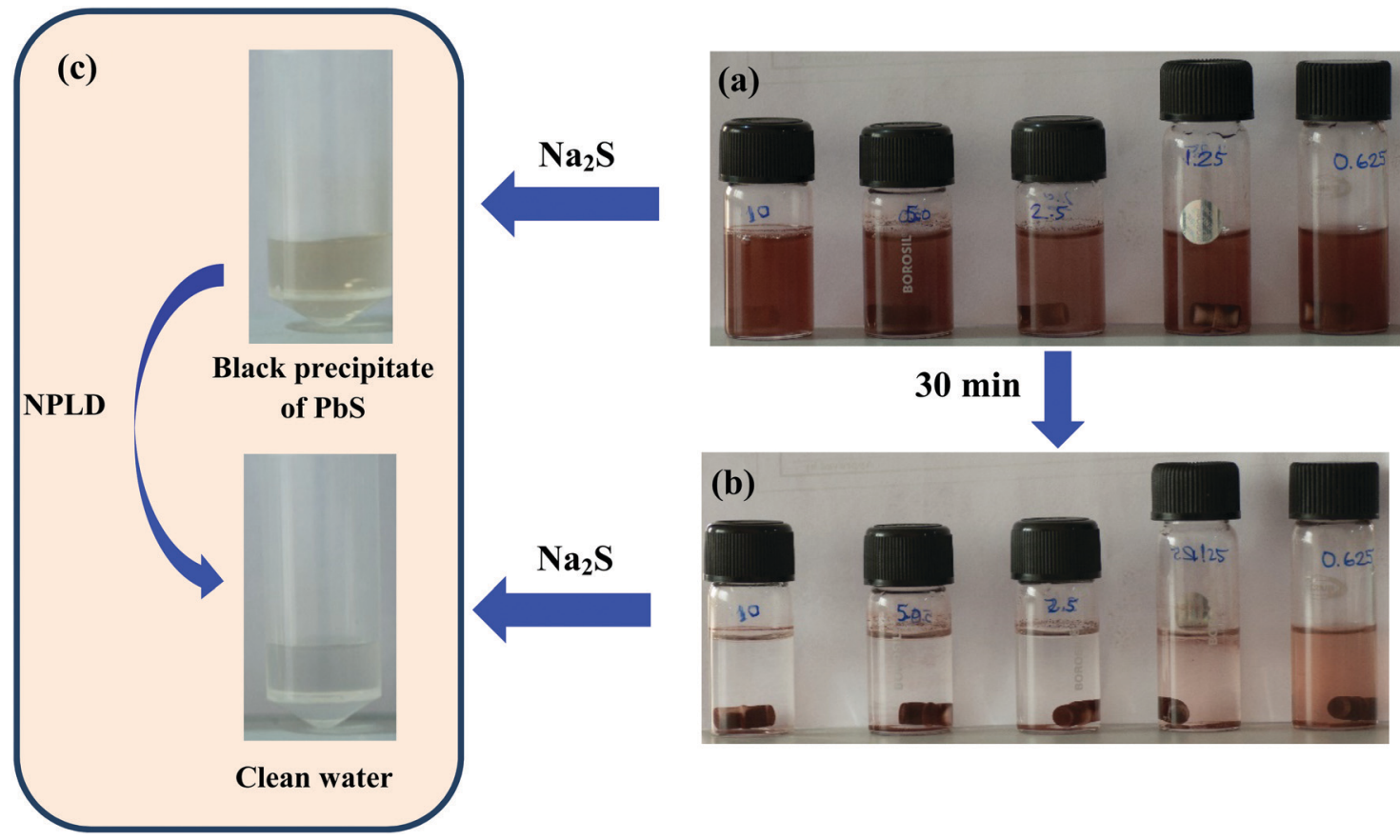

\section{$30 \mathrm{~min}$}

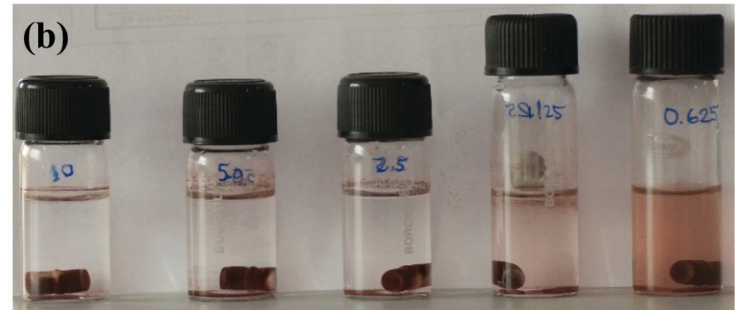

Fig. 9 Images of adsorption for different concentrations of Pb(॥) solutions by NPLD magnetic nanoparticles: (a) before and (b) after stirring with NPLD. Image (b) shows that higher interaction of NPLD with a high concentration of Pb(II), as indicated by magnetic removal in case of the far left vial. (c) Image taken after the addition of $\mathrm{Na}_{2} \mathrm{~S}$ to the $\mathrm{Pb}(I)$ solution before and after treating the $\mathrm{Pb}(\|)$ solution with NPLD, indicating there is no precipitation (PbS) in the solution that was treated with NPLD.

this slightly increased upon increasing the $\mathrm{pH}$ to 8 , the relative deprotonation became higher when the $\mathrm{pH}$ increased, which is represented in the bar plot given in Fig. S2 (ESI†). This high adsorption efficiency in a broad $\mathrm{pH}$ range proves that the material can be useful in industrial applications. For future applications we propose making of a cost efficient cartridge out of this material following magnetic separation technique. Furthermore, the regeneration studies are important from an industrial point of view in order to understand the reusability. The $\mathrm{Pb}^{2+}$ loaded NPLD was regenerated by collecting it with the assistance of a magnet and they were washed thoroughly using distilled water to remove any unabsorbed $\mathrm{Pb}^{2+}$, then $0.01 \mathrm{~mol} \mathrm{~L}^{-1}$ of a $20 \mathrm{~mL}$ EDTA solution was added, the solution was shaken mechanically for $24 \mathrm{~h}$ as

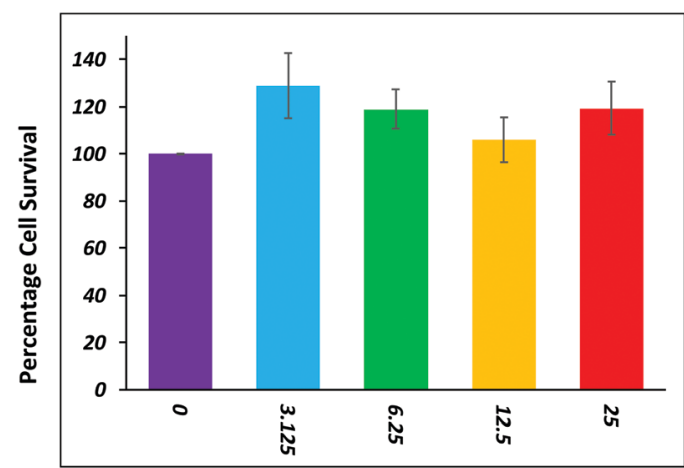

Concentration of Nanoparticles

Fig. 10 The effect of NPLD on WI-38 cell viability with varying concentrations of NPLD. reported previously ${ }^{43,46,73,74}$ and this was repeated four times. The nanoparticles were removed by magnetic separation and ICP-OES was used to investigate the reusability. The regenerated NPLD showed an excellent recyclability with a negligible loss of efficiency. Fig. S3 (ESI $\dagger$ ) shows all four cycles and reveals that the recovery is more than $89 \%$, meaning it is an excellent costefficient material for industrial use. Now it is highly desirable for a material that is to be used for practical applications to be non-toxic to cells. The toxicity of NPLD was evaluated using WI-38 fibroblasts cell..$^{54,84-86}$ It was found that more than $90 \%$ cells were alive and healthy upon incubation of NPLD with WI-38 for $24 \mathrm{~h}$ (Fig. 10). Therefore NPLD will be a suitable candidate for future practical applications in making lead guards for water purifiers.

\section{Conclusion}

Our skillfully engineered nanomaterial composed of PDI is a state-of-the-art material for use in the field of decontamination of lead from water owing to the presence of cost-efficient multifunctional perylene diimide with biocompatible L-DOPA at the imide position. The surface of the magnetic nano particles is coated with photostable and chemically inert rylene derivatives (perylene diimide). Owing to the presence of many hydroxyl and carboxyl groups on the surface of NPLD, it is highly dispersible in water and can capture lead selectively. The mode of application is $\mathrm{pH}$ independent and this material can withstand acid or basic harsh environments without affecting the adsorption of lead ions with a high adsorption capacity of $1407.5 \mathrm{mg} \mathrm{g}^{-1}$ and a $K_{\mathrm{d}}$ value of $1.14 \times 10^{6} \mathrm{~mL} \mathrm{~g}^{-1}$. NPLD maintains 
its high adsorption capacity even upon regeneration and reuse. It is effective in the presence of high concentrations of background metal ions such as $\mathrm{Na(I)}, \mathrm{K}(\mathrm{I}), \mathrm{Ca}(\mathrm{II}), \mathrm{Mg}$ (II) and $\mathrm{Zn}$ (II). Our magnetic nanomaterial is non-toxic to normal cells, therefore it can be applied practically for making lead guards in water purifiers. The material has excellent future perspectives for application in industry for lead removal from water as giant reactors or cartridges can be prepared containing such nanomaterials, and which will have no separation issues after use as they can easily be separated out by simple magnetic attraction.

\section{Conflicts of interest}

There are no conflicts to declare.

\section{Acknowledgements}

Dr. P. K. Sukul acknowledges the DST INSPIRE Faculty project, Department of Science and Technology, Govt. of India (project no. DST/INSPIRE/04/2015/002584) for financial support. S. Dey acknowledges DST, Govt. of India for fellowship. Authors also acknowledge Calcutta University-University with Potential for Excellence (CU-UPE) for infrastructural support of Inductively Coupled Plasma Optical Emission Spectroscopy (ICP-OES). We are thankful to Prof. S. Malik (IACS Kolkata) for valuable discussions. We are immensely indebted to IACS Kolkata for use of the instrumental facilities.

\section{Notes and references}

1 T. Oki and S. Kanae, Science, 2006, 313, 1068-1072.

2 C. J. Vörösmarty, P. B. McIntyre, M. O. Gessner, D. Dudgeon, A. Prusevich, P. Green, S. Glidden, S. E. Bunn, C. A. Sullivan, C. R. Liermann and P. M. Davies, Nature, 2010, 467, 555-561.

3 J. O. Nriagu and J. M. Pacyna, Nature, 1988, 333, 134-139.

4 M. Jaishankar, T. Tseten, N. Anbalagan, B. B. Mathew and K. N. Beeregowda, Interdiscip. Toxicol., 2014, 7, 60-72.

5 Human Lead Exposure, ed. H. L. Needleman, CRC Press, Boca Raton, FL, 1992.

6 D. R. Smith, M. W. Kahng, B. Quintanilla-Vega and B. A. Fowler, Chem.-Biol. Interact., 1998, 115, 39-52.

7 M. C. Carpenter, A. S. Shah, S. DeSilva, A. Gleaton, A. Su, B. Goundie, M. L. Croteau, M. J. Stevenson, D. E. Wilcox and R. N. Austin, Metallomics, 2016, 8, 605-617.

8 M. Kirberger, H. C. Wong, J. Jiang and J. J. Yang, J. Inorg. Biochem., 2013, 125, 40-49.

9 E. Bitto, C. A. Bingan, G. E. Wesenberg, J. G. McCoy and G. N. Phillips, J. Biol. Chem., 2006, 281, 20521-20529.

10 C. C. Bridges and R. K. Zalups, Toxicol. Appl. Pharmacol., 2005, 204, 274-308.

11 N. Ballatori, Environ. Health Perspect., 2002, 110, 689-694.

12 S. N. Kelada, E. Shelton, R. B. Kaufmann and M. J. Khoury, Am. J. Epidemiol., 2001, 154, 1-13.
13 I. A. Bergdahl, A. Grubb, A. Schütz, R. J. Desnick, J. G. Wetmur, S. Sassa and S. Skerfving, Pharmacol. Toxicol., 1997, 81, 153-158.

14 F. M. Johnson, Mutat. Res., 1998, 410, 123-140.

15 P. Apostoli, A. Bellini, S. Porru and L. Bisanti, Am. J. Ind. Med., 2000, 38, 310-315.

16 J. Bressler, K. Kim, T. Chakraborti and G. Goldstein, Neurochem. Res., 1999, 24, 595-600.

17 M. H. H. Price, Rep. Prep. Skeena Wild Conserv. Trust., 2013, 64, 9-36.

18 G. J. Atchison, M. G. Henry and M. B. Sandheinrich, Environ. Biol. Fishes, 1987, 18, 11-25.

19 R. Srikanth, A. M. Rao, C. S. Kumar and A. Khanum, Bull. Environ. Contam. Toxicol., 1993, 50, 138-143.

20 N. L. Gale, C. D. Adams, B. G. Wixson, K. A. Loftin and Y. Huang, Environ. Geochem. Health, 2004, 26, 37-49.

21 J. E. Poldoski, E. N. Leonard, J. T. Fiandt, L. E. Anderson, G. F. Olson and G. E. Glass, J. Great Lakes Res., 1978, 4, 206-215.

22 C. Ingraham, This is How Toxic Flint's Water really is. https:/www.washingtonpost.com/news/wonk/wp/2016/01/ 15/this-is-howtoxic-flints-waterreally-is/.

23 M. B. Pell and J. Schneyer, Off the Charts: The thousands of U.S. locales where Lead Poisoning is worse than Flint. http:// www.reuters.com/investigates/special-report/usa-lead-testing/, (accessed 2016).

24 Maximum contaminant level goals and national primary drinking water regulations for lead and copper; Federal Register, 2010.

25 WHO Guidelines for drinking-water quality, World Health Organization, 2005, pp. 104-108.

26 M. Kumar and A. Puri, Indian J. Occup. Environ. Med., 2012, 16, 40-44.

27 Lead-Environmental Aspects. Geneva, World Health Organization, Environmental Health Criteria 85, 1989.

28 J. Liu, Y. Ma, T. Xu and G. Shao, J. Hazard. Mater., 2010, 178, 1021.

29 L. Jiang and P. Liu, Ind. Eng. Chem. Res., 2014, 53, 2924-2931.

30 G. Aragay, J. Pons and A. Merkoçi, Chem. Rev., 2011, 111, 3433-3458.

31 M. Khajeh, S. Laurent and K. Dastafkan, Chem. Rev., 2013, 113, 7728-7768.

32 M. Arbabi, S. Hemati and M. Amiri, Int. J. Epidemiol. Res., 2015, 2, 105-109.

33 A. P. Lim and A. Z. Aris, Rev. Environ. Sci. Biotechnol., 2014, 13, 163-181.

34 F. Fu and Q. Wang, J. Environ. Manage., 2011, 92, 407-418. 35 A. Shafaei, M. Rezayee, M. Arami and M. Nikazar, Desalination, 2010, 260, 23-28.

36 A. Khelifa, S. Moulay and A. W. Naceur, Desalination, 2005, 181, 27-33.

37 P. Vandezande, L. E. M. Gevers and I. F. J. Vankelecom, Chem. Soc. Rev., 2008, 37, 365-405.

38 J. H. Huang, G. M. Zeng, C. F. Zhou, X. Li, L. J. Shi and S. B. He, J. Hazard. Mater., 2010, 183, 287-293. 
39 J. Yuan, X. Liu, O. Akbulut, J. Hu, S. L. Suib, J. Kong and F. Stellacci, Nat. Nanotechnol., 2008, 3, 332-336.

40 X. Zhao, X. Bu, T. Wu, S. T. Zheng, L. Wang and P. Feng, Nat. Commun., 2013, 4, 2344.

41 L. Li, S. Xiang, S. Cao, J. Zhang, G. Ouyang, L. Chen and C. Y. Su, Nat. Commun., 2013, 4, 1774.

42 C. Yu, Z. Shao and H. Hou, Chem. Sci., 2017, 8, 7611-7619.

43 D. T. Sun, L. Peng, W. S. Reeder, S. M. Moosavi, D. Tiana, D. K. Britt, E. Oveisi and W. L. Queen, ACS Cent. Sci., 2018, 4, 349-356.

44 X. Tan, H. Zhu, J. Yuan, W. Zhang, M. Fang and X. Wang, Environ. Sci.: Nano, 2019, 6, 261.

45 C. Y. Cao, J. Qu, F. Wei, H. Liu and W. G. Song, ACS Appl. Mater. Interfaces, 2012, 4, 4283-4287.

46 T. V. J. Charpentier, A. Neville, J. L. Lanigan, R. Barker, M. J. Smith and T. Richardson, ACS Omega, 2016, 1, 77-83.

47 K. A. López, M. N. Piña, D. Quiñonero, P. Ballester and J. Morey, J. Mater. Chem. A, 2014, 2, 8796-8803.

48 K. Chen, J. He, Y. Li, X. Cai, K. Zhang, T. Liu, Y. Hu, D. Lin, L. Kong and J. Liu, J. Colloid Interface Sci., 2017, 494, 307-316.

49 S. Kumar, R. R. Nair, P. B. Pillai, S. N. Gupta, M. A. R. Iyengar and A. K. Sood, ACS Appl. Mater. Interfaces, 2004, 6, 17426-17436.

50 Y. Bagbi, A. Sarswat, D. Mohan, A. Pandey and P. R. Solanki, Sci. Rep., 2017, 7, 7672.

51 D. Görl, X. Zhang and F. Würthner, Angew. Chem., Int. Ed., 2012, 51, 2-23.

52 M. Sun, K. Müllen and M. Yin, Chem. Soc. Rev., 2016, 45, 1513-1528.

53 E. Krieg, H. Weissman, E. Shirman, E. Shimoni and B. A. Rybtchinski, Nat. Nanotechnol., 2011, 6, 141-146.

54 F. Liu, J. Mu, X. Wu, S. Bhattacharya, E. K. L. Yeow and B. Xing, Chem. Commun., 2014, 50, 6200-6203.

55 Z. Luo, T. Liu, Z. Chen, Y. Xiao, G. Zhang, L. Huo, C. Zhong, X. Lu, H. Yan, Y. Sun and C. Yang, Adv. Sci., 2019, 6, 1802065.

56 A. Zhang, W. Jiang and Z. Wang, Angew. Chem., Int. Ed., 2020, 59, 752-757.

57 B. Liu, M. Böckmann, W. Jiang, N. L. Doltsinis and Z. Wang, J. Am. Chem. Soc., 2020, 142, 7092-7099.

58 F. Würthner, C. R. Saha-Möller, B. Fimmel, S. Ogi, P. Leowanawat and D. Schmidt, Chem. Rev., 2016, 116, 962-1052.

59 R. M. Pinder, Nature, 1970, 228, 358.

60 Q. Zhang, Q. Yang, P. Phanlavong, Y. Li, Z. Wang, T. Jiao and Q. Peng, ACS Sustainable Chem. Eng., 2017, 5, 4161-4170.

61 C. Huang, S. Barlow and S. R. Marder, J. Org. Chem., 2011, 76, 2386-2407.
62 P. K. Sukul, D. Asthana, P. Mukhopadhyay, D. Summa, L. Muccioli, C. Zannoni, D. Beljonne, A. E. Rowan and S. Malik, Chem. Commun., 2011, 47, 11858.

63 W. Herbst and K. Hunger, Industrial Organic Pigents, Wiley-VCH, Weinheim, 2nd completely revised edn, 1997.

64 L. Guo, Q. Liu, G. Li, J. Shi, J. Liu, T. Wang and G. A. Jiang, Nanoscale, 2012, 4, 5864-5867.

65 L. J. Bellamy, The Infrared Spectra of Complex Molecules, Wiley, 1958.

66 L. Kong, L. Yan, Z. Qu, N. Yan and L. Li, J. Mater. Chem. A, 2015, 3, 15755-15763.

67 G. M. Sheldrick, SHELXS-97 and SHELXL-97, Program for $X$-ray Crystal Structure Solution, University of Göettingen, Germany, 1997.

68 P. Gong, J. Yu, H. Sun, J. Hong, S. Zhao, D. Xu and S. Yao, J. Appl. Polym. Sci., 2006, 101, 1283-1290.

69 S. Thanikaikarasan, T. Mahalingam, K. Sundaram, A. Kathalingam, Y. Deak Kim and T. Kim, Vacuum, 2009, 83, 1066-1072.

70 M. Monier and D. A. Abdel-Latif, J. Hazard. Mater., 2012, 209, 240-249.

71 Y. F. Lin, H. W. Chen, P. S. Chien, C. S. Chiou and C. C. Liu, J. Hazard. Mater., 2011, 185, 1124-1130.

72 M. R. Huang, Q. Y. Peng and X. G. Li, Chem. - Eur. J., 2006, 12, 4341-4350.

73 C. S. Kam, T. L. Leung, F. Liu, A. B. Djurišić, M. H. Xie, W. K. Chan and K. Shih, RSC Adv., 2018, 8, 18355-18362.

74 Y. L. F. Musico, C. M. Santos, M. L. P. Dalida and D. F. Rodrigues, J. Mater. Chem. A, 2013, 1, 3789.

75 Y. S. Ho and G. McKay, Chem. Eng. J., 1998, 70, 115-124.

76 Y. Shin, G. E. Fryxell, W. Um, K. Parker, S. V. Mattigod and R. Skaggs, Adv. Funct. Mater., 2007, 17, 2897-2901.

77 A. Moradi, P. N. Moghadam, R. Hasanzadeh and M. Sillanpää, RSC Adv., 2017, 7, 433-448.

78 M. Lu, L. Li, S. Shen, D. Chen and W. Han, New J. Chem., 2019, 43, 1032.

79 L. Ma, Q. Wang, S. M. Islam, Y. Liu, S. Ma and M. G. Kanatzidis, J. Am. Chem. Soc., 2016, 138, 2858-2866.

80 Z. Tan, H. Peng, H. Liu, L. Wang, J. Chen and X. Lu, J. Appl. Polym. Sci., 2015, 132, 4238.

81 R. G. Pearson, J. Am. Chem. Soc., 1963, 85, 3533-3539.

82 M. L. Feng, D. Sarma, X. H. Qi, K. Z. Du, X. Y. Huang and M. G. Kanatzidis, J. Am. Chem. Soc., 2016, 138, 12578-12585.

83 L. Zeng, Y. Chen, Q. Zhang, X. Guo, Y. Peng, H. Xiao, X. Chen and J. Luo, Carbohydr. Polym., 2015, 130, 333-343.

84 J. McCarthy and R. Weissleder, Adv. Drug Delivery Rev., 2008, 60, 1241-1251.

85 H. A. Kahil, Rom. J. Biophys., 2020, 30, 39-48.

86 A. Kumar, P. K. Jena, S. Behera, R. F. Lockey, S. Mohapatra and S. Mohapatra, Nanomedicine, 2010, 6, 64-69. 